\title{
The Elegance of Sonic Hedgehog: Emerging Novel Functions for a Classic Morphogen
}

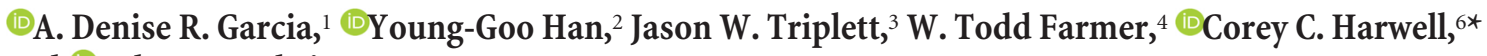 \\ and ${ }^{\circ}$ Rebecca A. Ihrie ${ }^{5 *}$ \\ ${ }^{1}$ Departments of Biology and Neurobiology and Anatomy, Drexel University, Philadelphia, Pennsylvania, Philadelphia, PA 19146, ${ }^{2}$ Department of \\ Developmental Neurobiology, Neurobiology and Brain Tumor Program, St. Jude Children's Research Hospital, Memphis, Tennessee, Memphis, TN 38105, \\ ${ }^{3}$ Center for Neuroscience Research, Children's National Medical Center, Departments of Pediatrics and Pharmacology and Physiology, The George \\ Washington University School of Medicine and Health Sciences, Washington, District of Columbia, Washington, District of Columbia, 20010, ${ }^{4}$ Centre for \\ Research in Neuroscience, Department of Neurology and Neurosurgery, Brain Repair and Integrative Neuroscience Program, The Research Institute of the \\ McGill University Health Center, Montreal General Hospital, Montreal, Quebec, Canada, H3G 1A4, ${ }^{5}$ Departments of Cell and Developmental Biology and \\ Neurological Surgery, Vanderbilt University School of Medicine, Nashville, Tennessee, TN, 37232-6840, and ${ }^{6}$ Department of Neurobiology, Harvard \\ Medical School, Boston, Massachusetts, MA 02115
}

Sonic Hedgehog (SHH) signaling has been most widely known for its role in specifying region and cell-type identity during embryonic morphogenesis. This mini-review accompanies a 2018 SFN mini-symposium that addresses an emerging body of research focused on understanding the diverse roles for Shh signaling in a wide range of contexts in neurodevelopment and, more recently, in the mature CNS. Such research shows that Shh affects the function of brain circuits, including the production and maintenance of diverse cell types and the establishment of wiring specificity. Here, we review these novel and unexpected functions and the unanswered questions regarding the role of $\mathrm{SHH}$ and its signaling pathway members in these cases.

\section{Introduction}

Sonic Hedgehog ( $\mathrm{SHH})$ is a secreted factor; the protein is heavily modified through cleavage and posttranslational modification and its release from producing cells can also be modulated by interactions with Dispatched, Scube2, and heparan sulfate proteoglycan (Burke et al., 1999; Rubin et al., 2002; Tukachinsky et al., 2016). A growing list of genes encoding Shh receptor and coreceptor proteins, including BOC, CDON, GAS1, and glypicans, are expressed in cell-type- and developmental-stage-specific patterns in the nervous system and this variety likely contributes to the diversity of cellular responses to Shh.

The core components of the canonical Shh signaling pathway include Patched1 (PTCH1), the 12-pass transmembrane receptor that binds SHH directly; Smoothened (SMO), an obligate core-

\footnotetext{
Received Aug. 2, 2018; revised Sept. 27, 2018; accepted Sept. 28, 2018.

This work was supported by National Institutes of Health Grants K01NS098720 and R01NS10228 to C.C.H and NIH R01NS096238, DOD W81XWH-16-10171, Michael David Greene Brain Cancer Fund, Vanderbilt-Ingram Cancer (P30CA68485) and Southeastern Brain Tumor Foundation to R.A.l., NIH R21MH110724, R01NS096100, K01MH097957 and Cure Tobacco Formula Funds to A.D.R.G., Whitehall Foundation and NIH R01NS100939 to Y-.G.H., NIH R01EY025627 and NCATS UI1TR000075 to J.W.T, Research Institute of the McGill University Health Centre and Nature Sciences and Engineering Council of Canada and Brain Canada with the W. Garfield Weston Foundation to W.T.F.

The authors declare no competing financial interests.

${ }^{*}$ C.C.H. and R.A.I. contributed equally to this work.

Correspondence should be addressed to either of the following: Corey Harwell, Department of Neurobiology, Harvard Medical School, 25 Shattuck St, Boston, MA 02115. E-mail: corey_harwell@hms.harvard.edu; or Rebecca Ihrie, Department of Cell \& Developmental Biology, 2220 Pierce Ave, 761 PRB, Nashville, TN 37232-6840. E-mail: rebecca.ihrie@vanderbilt.edu.

DOI:10.1523/JNEUROSCI.1662-18.2018

Copyright $\odot 2018$ the authors $\quad 0270-6474 / 18 / 389338-08 \$ 15.00 / 0$
}

ceptor the repression of which by PTCH1 is relieved upon ligand binding; and the GLI family of transcription factors, which includes GLI1, GLI2, and GLI3. Binding of PTCH1 by the SHH ligand releases the repression of SMO, enabling the subsequent modulation of the cleavage and stability of GLI2 and GLI3. Ultimately, this shift in processing of GLI2/3 results in a shift from transcriptional repression mediated through GLI3R to transcriptional activation and, at the highest levels of activity, GLI2mediated transcription of the constitutive activator GLI1. In many, but not all cases, the interactions among PTCH1, SMO, and modulation of GLI proteins appear to be localized to the primary cilium, a microtubule-based organelle that functions as a signaling center within the cell. Developmental disorders affecting the primary cilium share many features with disorders in which Shh pathway components are disrupted.

The novel roles reviewed here require various components of this multifaceted pathway, with some events requiring "canonical" induction of transcriptional programs and others acting through signal transduction that is independent of the GLI factors. Recent investigations have identified functions for Shh pathway members in the regulation of early and late stem and progenitor cells, in the establishment of circuitry, and in communication between neurons and astrocytes within mature circuitry.

\section{Shh signaling in neocortical progenitor expansion}

Shh signaling has a long-known role in the regulation of neural progenitors (NPs) of the rostral neural tube, where it is required to establish distinct brain regions and to balance the number and 
type of neurons and glial cells produced (Fuccillo et al., 2006). In the developing neocortex, the primary NPs are the ventricular radial glia (vRG, also called apical RG), which produce neurons directly or indirectly via the outer RG (oRG, also called basal RG) and/or intermediate progenitors (IPs). Neocortical expansion and folding requires two coordinated processes that depend on NPs: the increased production and the tangential dispersion of new neurons. Recent findings show that Shh signaling is central to the mechanisms that promote growth and folding of the neocortex.

In mice, perturbations in Shh signaling cause defective proliferation of IPs and microcephaly (Komada et al., 2008). Furthermore, a recent study showed that Shh signaling is sufficient for both IP and oRG expansion and neocortical growth (Wang et al., 2016). Remarkably, elevated Shh signaling increases upper layer neuron production from mid-corticogenesis at embryonic day 13.5 (E13.5) on, leading to neocortical growth and folding in the otherwise-smooth mouse neocortex. Ectopic activation of high Shh signaling, via induction of the SMOM2 allele, which encodes a tumor-derived constitutively active SMO protein, elicits two developmental characteristics that are absent in mouse but have been proposed to be necessary and sufficient for the evolution of an expanded and folded neocortex: oRG expansion and recurrent self-amplifying IP divisions (Lewitus et al., 2014). Elevated Shh signaling in early corticogenesis (E9-E10) misspecifies cortical NPs, and decreases IPs (Dave et al., 2011; Shikata et al., 2011; Wang et al., 2011; Yabut et al., 2015), demonstrating developmental stage-specific functions of Shh signaling.

Shh signaling is also important for neocortical growth in gyrencephalic species. GLI1, the expression of which provides a faithful readout of Shh signaling, is highly expressed in human vRG (Wang et al., 2016) and mutations disrupting Shh signaling cause microcephaly in humans (Heussler et al., 2002; Derwińska et al., 2009; Izumi et al., 2011). In ferrets, Gli1 expression is significantly higher in the ventricular zone (VZ) area that generates a thick subventricular zone (SVZ) containing many oRG, than in the $\mathrm{VZ}$ area that gives rise to a thin SVZ containing fewer oRG (de Juan Romero et al., 2015). Consistent with this, in human cerebral organoids (Lancaster et al., 2013), blocking SHH signaling decreases the number of oRG detected in human cerebral organoids (Wang et al., 2016). GLI1 transcription is significantly higher in human fetal neocortex than in mouse embryonic cortex (Wang et al., 2016), consistent with more abundant oRG and IPs in human than mouse fetal cortex. Understanding underlying mechanisms for this differential Shh signaling activity, as well as molecular mechanisms by which Shh signaling expands oRG and IPs, will provide fundamental insights into the development and evolution of mammalian brains and the etiology of neurodevelopmental diseases.

Beyond its multifaceted activity in the neocortex, Shh has a well established role in the patterning of the subpallium, including the medial ganglionic eminence and the more caudal neural tube, where it is a major ventralizing factor (Echelard et al., 1993; Riddle et al., 1993; Ericson et al., 1995; Kohtz et al., 1998). More recent studies of Shh signaling in late embryogenesis have also revealed a requirement for cortical neuron- and interneuron-derived SHH ligand in the production of oligodendrocytes (Winkler et al., 2018). In postnatal brain, the persistent stem cell niches of both the ventricular subventricular zone (V-SVZ) and dentate gyrus (DG) are sites of continued Shh signaling, with multiple effects on neural versus glial fate selection and stem cell activity.

\section{Shh regulates positional identity in the postnatal neural stem cell (NSC) niche}

After birth, Gli1 transcript displays a localized pattern within the V-SVZ. This niche of glial-like progenitors is organized into distinct subdomains committed to specific progeny fates, with ventral stem cells primarily generating immature neuroblasts, which then integrate into the olfactory bulb as deep granule interneurons. Examination of reporter alleles driven by Gli1 (Ahn and Joyner, 2004, 2005) and lineage tracing at distinct postnatal time points in the mouse revealed that, whereas SMO is broadly expressed, high SHH activity and Gli1 expression are predominantly ventral, where they are necessary and sufficient to generate deep granule interneurons in the olfactory bulb (Ihrie et al., 2011). However, dorsal V-SVZ Gli1 is also observed during a wave of early postnatal oligodendrogenesis (Tong et al., 2015). Forced ectopic activation of high Shh signaling via induction of the SMOM2 allele is sufficient to drive Gli1 expression and to shift cell fate to oligodendroglial and deep granule cell fates, indicating that high SHH signaling can drive the adoption of ventral identities in this postnatal niche. Removal of inhibition of this pathway (via deletion of the transcriptional repressor GLI3) in dorsal cells, transplantation of dorsal cells to a ventral location, or the combination of these two manipulations does not result in a change of identity, suggesting that the induction of GLI1 is tightly regulated and might not be overcome in all experimental conditions (Petrova et al., 2013) (R.A.I., unpublished data).

Intriguingly, modulations of other Shh pathway members indicate that lower levels of pathway activity, which would result in relief of GLI2/3-mediated repression but not expression of GLI1, likely have additional, broader functions in regulating the full dorsoventral stem cell niche. Ablation of the inhibitory coreceptor PTCH1 results in an accumulation of quiescent NSCs at the expense of more proliferative and differentiated progeny, indicating that inhibition of Shh signaling is required to maintain the balance between NSC quiescence and activation (Daynac et al., 2016). Ablation of GLI3 throughout the V-SVZ niche is sufficient to rescue many of the broad neurogenesis phenotypes seen when Smoothened is lost, suggesting that relief from GLI3-mediated repression by low Shh signaling is required for normal stem cell activity (Balordi and Fishell, 2007a,b; Petrova et al., 2013). Similarly, in the DG, detection of transcript and study of reporter alleles indicates that GLI1-positive cells are present within the stem cell pool and that SMO ablation (with a consequent increase in GLI3-mediated repression) significantly disrupts neurogenic activity (Ahn and Joyner, 2005; Han et al., 2008; Shin et al., 2015). In contrast to the V-SVZ, which is spread over a large spatial area and generates migratory progeny that integrate far from the niche, the DG is contained within a smaller area and generates neurons that integrate locally. As a consequence, potential heterogeneity in the function or localization of specific NSC subsets is not yet fully delineated in this niche.

The multiple requirements for Shh pathway members in the postnatal stem cell niches of the V-SVZ and DG raise several questions for future research. Intriguingly, studies of GLI1 expression in models of demyelinating lesions indicate that, whereas GLI1-expressing cells are mobilized to generate oligodendrocytes after damage, inhibition of GLI1 enhances the maturation of these oligodendrocytes and recovery after injury (Samanta et al., 2015). It will be of interest to test whether this production of oligodendrocytes after injury recapitulates the earlier postnatal oligodendrogenesis program. Similarly, it is not yet clear whether the pattern of Shh activity in the stem cell niche is 
altered after other injuries or after repeated antimitotic challenge. Finally, whereas both the choroid plexus and local neurons in the basal forebrain and hilus have been identified as potential sources of SHH ligand, how this ligand is dynamically conveyed to GLI1expressing cells and the broader V-SVZ and DG niches is not yet clear (Lai et al., 2003; Machold et al., 2003). Recent findings using live-tissue imaging in embryonic tissue indicate that, in some cases, SHH ligand may also be transported over longer distances via specialized signaling filopodia known as cytonemes or other dynamic projections that are not evident in fixed specimens (Sanders et al., 2013). However, whether such projections occur in the more restrictive tissue environment of the mature, myelinated brain remains to be investigated.

\section{Shh signaling during circuit wiring}

As secreted molecules that act over long distances, morphogens such as $\mathrm{SHH}$ are ideally situated to guide axonal projections as they innervate target regions and establish connectivity. Indeed, multiple morphogens, including WNTs, BMPs, and $\mathrm{SHH}$, are repurposed to mediate axon guidance in multiple regions of the developing nervous system (Yam and Charron, 2013; Zuñiga and Stoeckli, 2017). The ability of SHH to function as an axon guidance molecule was first demonstrated in RGCs (Trousse et al., 2001). Recent work has elucidated the molecular underpinnings of Shh-mediated guidance in two critical processes: proper crossing of commissural axons at the spinal cord midline commissure and sorting of contralaterally and ipsilaterally projecting retinal ganglion cells (contra- and ipsi-RGCs) at the optic chiasm. In the mouse visual system, ipsi-RGCs originating from the ventrotemporal retina do not cross the optic chiasm, facilitating coherent processing of the contralateral visual hemifield. Disruption of Shh signaling through function-blocking antibodies or Boc deletion disrupts axon organization at the chiasm, ipsi-RGC guidance, and eye-specific segregation in the retinorecipient dorsal lateral geniculate nucleus (Sánchez-Camacho and Bovolenta, 2008; Fabre et al., 2010; Sánchez-Arrones et al., 2013). Shh is expressed exclusively by contra-RGCs, whereas Boc and Ptc2 are expressed by ipsi-RGCs (Sánchez-Camacho and Bovolenta, 2008). Furthermore, Boc expression in contra-RGCs is sufficient to misroute them ipsilaterally (Fabre et al., 2010). Shh is not expressed by cells at the optic chiasm, suggesting a mechanism for guidance distinct from that used by spinal commissural axons. A recent, elegant study demonstrated that Shh expressed by contraRGCs is trafficked to the chiasm, where it is enriched and repels ipsi-RGCs (Peng et al., 2018). This type of trans-axonal signaling represents a novel mechanism to ensure proper sorting at the chiasm. Intriguingly, recent data suggest that the Shh signaling component (Hedgehog interacting protein (HHIP) is also present in retinorecipient regions (U. Javed and J.W.T., unpublished observations), raising the possibility that this multifunctional molecule may serve yet another purpose in the assembly of visual system circuitry.

Neurons located in the developing dorsal spinal cord extend axons toward the ventral floor plate, where they cross to the contralateral side and turn anteriorly (Evans and Bashaw, 2010). Similar to other guidance cues, SHH plays a dual role in this system, acting as both a chemoattractant and a chemorepellant. In combination with Netrin1, $\mathrm{SHH}$ is secreted from the floor plate, establishing a high-ventral to low-dorsal gradient of attractants for dorsal neurons (Charron et al., 2003; Kennedy et al., 2006). Shh-mediated attraction requires SMO (Charron et al., 2003), as well as the coreceptor BOC (Okada et al., 2006). Unlike its morphogenic effects, Shh-induced attraction is not transcrip- tionally mediated, but it does require new protein translation. Through a noncanonical pathway, $\mathrm{SHH}$ activates Src family kinases (SFKs) (Yam et al., 2009), well known regulators of the cytoskeleton during axon guidance (Robles et al., 2005). SFKphosphorylated zipcode binding protein 1 (ZBP1) then induces local translation of $\beta$-actin in the growth cone, driving axon attraction to the floor plate (Lepelletier et al., 2017). More recently, it has been shown that the guanine nucleotide exchange factors DOCK 3 and 4 and their binding partners ELMO1 and 2 are required for cytoskeletal remodeling during axon attraction. After axons have crossed the midline, temporally regulated expression of 14-3-3 adapter protein isoforms, which reduce protein kinase A activity, function to switch $\mathrm{SHH}$ responsiveness from attraction to repulsion (Yam et al., 2012). After midline crossing, axons are repelled toward the anterior by a posterior-high gradient of SHH along the neural tube.

HHIP is a SHH receptor that has also been implicated in axon repulsion. In the developing chick spinal cord, Hhip is transiently expressed at the time when axons of commissural neurons cross the midline (Bourikas et al., 2005). Hhip upregulation is triggered by $\mathrm{SHH}$ binding to Glypican 1 (Gpc1), a membrane-tethered glycoprotein (Wilson and Stoeckli, 2013). How Gpc1 signals to activate HHIP expression is unclear, as is the mechanism by which HHIP, which lacks an intracellular domain, mediates repulsion from the midline. One mechanism by which HHIP could influence axon guidance, however, is to sequester $\mathrm{SHH}$ and thus inactivate signaling (Chuang and McMahon, 1999). Hhip ${ }^{-1-}$ embryos did not display guidance defects, raising the possibility that HHIP may function redundantly, as has been observed with other $\mathrm{SHH}$ receptors (Allen et al., 2011; Yam et al., 2012). Alternatively, HHIP may have essential functions in other aspects of circuit development independent of axon repulsion.

\section{Shh signaling during synapse formation}

After an axon reaches its target region, it is surrounded by a sea of potential synaptic partners, of which only a subset are appropriate targets. Although tremendous progress has been made in characterizing many of the long-range cues required to guide axons into their target region, the cellular mechanism by which neurons choose synaptic partners is still not fully understood (Charron et al., 2003; Yam and Charron, 2013; Belgacem et al., 2016; Zuñiga and Stoeckli, 2017). Several lines of evidence in both invertebrates and vertebrates suggest that Shh signaling has prominent functional roles during synapse formation and circuit assembly. In the Drosophila visual system, $\mathrm{SHH}$ derived from the axons of photoreceptor neurons signals to synaptic target neurons to promote differentiation and synapse formation (Chu et al., 2006; Belgacem et al., 2016). Recent studies in the mammalian cortex and hippocampus have likewise found that numerous components of the Shh signaling pathway are expressed in specific neural cell types. Both SMO and PTCH1 have been observed in the somatodendritic compartment of rat hippocampal neurons (Masdeu et al., 2007; Petralia et al., 2011). Moreover, treatment of cultured hippocampal neurons with exogenous SHH or Shh agonist has been shown to induce presynaptic differentiation and increase the size and number of presynaptic terminals (Mitchell et al., 2012). SHH itself is expressed in a variety of postmitotic neuronal cell types, including Purkinje cells (PCs) in the cerebellum and CA1 and CA3 pyramidal neurons in the hippocampus (Traiffort et al., 1999; Wechsler-Reya and Scott, 1999; Garcia et al., 2010; Harwell et al., 2012). In the cortex, SHH is expressed by layer $\mathrm{V}$ subcortical projection neurons, whereas BOC is expressed by layer II/III intracortical projection neurons 
that make synaptic connections onto layer $\mathrm{V}$ projection neurons (Harwell et al., 2012). Loss of Boc or Shh in cortical neurons disrupted functional connections between layer II/III neurons and their layer $\mathrm{V}$ synaptic targets, whereas layer II/III intralaminar connectivity was preserved. These studies demonstrate a specific requirement for Shh signaling during the final steps of synaptic partner selection in addition to its established role in guiding axons to target regions.

The precise molecular mechanism by which SHH directs synapse formation and specificity has yet to be addressed. It is currently unknown whether $\mathrm{SHH}$ functions as a permissive cue, signaling to incoming axons to begin synapse formation in their target layer, or as an instructive cue bound to the membrane of specific subsets of SHH-expressing neurons. It has been shown that Shh-dependent synapse formation between subsets of neurons in the cortex requires Boc expression, which is necessary for noncanonical Shh signaling. However, whether the same cytoskeletal regulatory pathways involved in Boc-dependent axon guidance are also involved in synapse formation has yet to be investigated.

\section{Shh signaling in astroglial cells of the CNS}

The conventional model of Shh signaling has focused predominantly on its roles in a wide range of neurodevelopmental processes that largely affect the development of neurons and oligodendrocytes. Less well understood is the role of Shh signaling in astroglial cells, the principal cells in the postnatal and mature brain where Shh activity persists (Garcia et al., 2010; Farmer et al., 2016). Astrocytes play key roles in a broad array of nervous system processes, including the nervous system response to injury and disease, maintenance of the blood-brain barrier (BBB), as well as synapse formation and function (Sofroniew and Vinters, 2010). The molecular mechanisms that mediate and regulate these processes are not fully understood, but an emerging body of evidence suggests a role for Shh.

Astrocytes are enriched for Smo, Ptch1, and Gli1 (Cahoy et al., 2008; Garcia et al., 2010; Ihrie et al., 2011; Farmer et al., 2016). Gli1 expression is restricted to discrete subpopulations of astrocytes throughout the brain (Garcia et al., 2010; Farmer et al., 2016), suggesting that Shh signaling may drive distinct molecular and functional programs. Indeed, in the cerebellum, two classes of astroglial cells possess unique molecular profiles that are dependent on Shh signaling (Farmer and Murai, 2017). Bergmann glia (BG) and velate astrocytes (VAs) were recognized as distinct cell types $>100$ years ago by Santiago Ramón y Cajal (Ramón y Cajal, 1911). BG are one of the few glial cells that retain a radial morphology within the adult brain. Their somata reside adjacent to PCs, where they project multiple radial processes across the molecular layer to form end feet on the basal lamina of the pial surface of the cerebellar cortex. This intimate association with PCs places BG as critical players in cerebellar physiology (Takayasu et al., 2006; Bellamy, 2007; Saab et al., 2012; Wang et al., 2012). Although BG have been extensively studied, very little is known about VAs outside of their morphology and spontaneous calcium transients (Chan-Palay and Palay, 1972; Hoogland and Kuhn, 2010). VAs are nonpolarized cells that tile the granule cell layer, where they project veil-like processes to envelope granule neuron somata and mossy fiber terminals. Given their vastly different environments, it is not surprising that BG and VAs display distinct gene expression profiles. BG express a defining array of transporters, channels, and receptors, including high levels of the glutamate transporter GLAST, the inward-rectifying potassium channel Kir4.1, and the ionotropic AMPA receptors GluA1 and
GluA4 (Rothstein et al., 1994; Iino et al., 2001; Saab et al., 2012; Farmer et al., 2016). Conversely, VAs express low levels of GLAST, Kir4.1, GluA1, and GluA4 while expressing high levels of the water channel AQP4 (Farmer et al., 2016).

The different location, morphology, and gene expression profile of BG and VAs hints at different developmental trajectories; however, it has been difficult to pinpoint where the two cell types diverge during development (Buffo and Rossi, 2013). Surprisingly, it was recently revealed that the molecular and physiologi$\mathrm{cal}$ properties of these astrocytes are determined, not by a developmental program, but rather by persistent signaling from PCs via the Shh pathway. Mature PCs secrete the SHH ligand, which signals to adjacent BG. Blocking Shh signaling in mature BG by Cre-Lox-mediated conditional KO of Smo results in the loss of GLAST, GluA1, GluA4, and Kir4.1 protein and increased expression of AQP4, an expression profile resembling that of VAs (Figure 1). In addition to altering gene expression, loss of Smo function in BG causes reduced AMPA-mediated currents indicating that the Shh pathway regulates intrinsic physiological properties of BG as well. Loss of the Shh ligand from discrete clusters of mature PCs phenocopies Smo loss-of-function in adjacent BG. Therefore, PC-derived Shh is responsible for maintaining the unique gene expression and physiology of BG. Interestingly, the profound changes in molecular phenotype caused by disrupting Shh signaling are not associated with gross alterations in BG morphology.

Whereas loss of Shh signaling in BG results in a VA-like molecular phenotype, activating the Shh pathway in mature VAs by the conditional expression of constitutively active Smoothened leads to the expression Glast, GluA1, and Kir4.1 and the reduction of AQP4. Therefore, mature VAs are not only responsive to Shh signaling, but also adopt a BG-like expression profile when the pathway is activated. As seen in BG, manipulating Shh signaling in VAs does not grossly affect morphology.

Together, these data show that the Shh pathway is both necessary and sufficient to maintain the BG-specific gene expression and physiology in cerebellar astrocytes. Therefore, persistent PC-BG signaling through Shh is a major determinant of cerebellar astrocyte phenotype (Farmer et al., 2016). Interestingly, Shh signaling does not regulate the expression of GLAST, GluA1, or GluA4 in the cerebral cortex or hippocampus, but Kir4.1 is induced in the forebrain and cerebellum in an Shh-dependent manner (Farmer et al., 2016), suggesting that astrocytes from different brain regions initiate distinct transcriptional programs in response to Shh pathway activation. Furthermore, the data suggest that, similar to the Glil-expressing astrocyte-like adult stem cells, the specialized properties of astrocytes require persistent reinforcement by extrinsic cues, illustrating that cellular diversity in the brain is not determined exclusively during development, but rather continues to be refined into adulthood (Farmer et al., 2016).

The observation that Shh regulates expression of several synaptic-related proteins suggests that it may play a role in mediating astrocyte-synapse interactions. Indeed, a growing body of evidence now shows that astrocytes regulate the formation of specific synaptic connections in the developing cortex (Allen and Eroglu, 2017). An intriguing question for the future is whether neuron-derived SHH coordinates the activities of both Bocexpressing neurons and Gli1-expressing astrocytes during circuit assembly and how these activities compare with the effects of Shh signaling in other functions of astrocytes.

In contrast to the cerebellum, where Gli1 expression identifies distinct classes of astroglial cells that are regionally and morpho- 


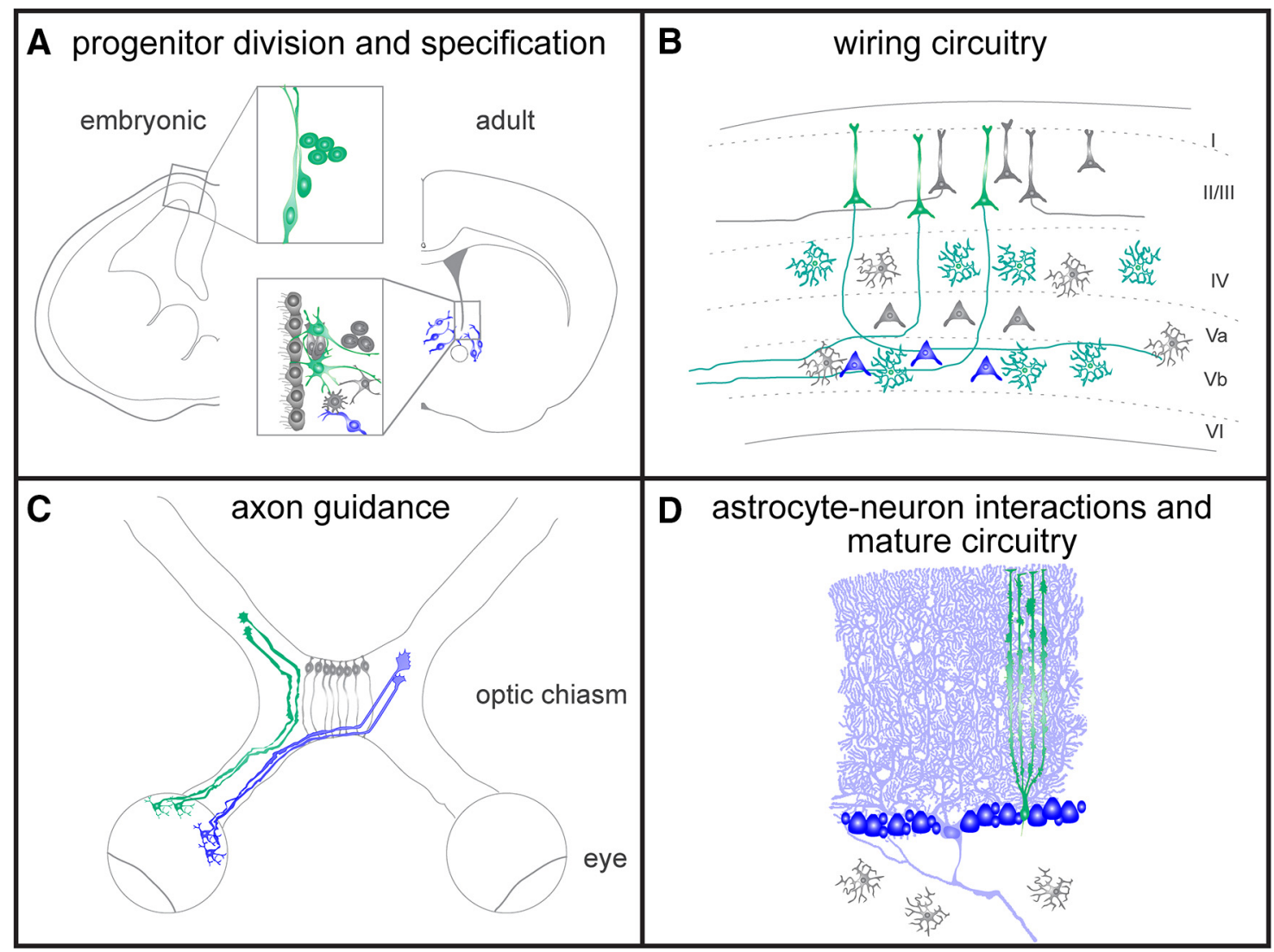

Figure 1. Simplified schematics of Shh signaling in the contexts discussed herein. Where known, the source of SHH ligand is indicated in blue and Shh-responsive cells are shown in green. $\boldsymbol{A}$, Shh signaling, primarily indicated by expression of Glii in stem and progenitor cells, is critical for stem cell division and specification in both the embryonic and mature brain. In the embryonic neocortex, Gli transcript is found in the VZ and the SVZ that contain radial glia and intermediate progenitors (all shown in green, inset) and elevation of Shh activity via expression of a constititutively active Smo (SmoM2) results in an expansion of oRG and IP populations. During development, many potential sources of SHH ligand exist, but the key source driving cortical signaling is not yet known. In the adult stem cell niche, Gli i is found in a ventrally located subset of stem/progenitor cells and is sufficient to impose a ventral identity when ectopically expressed. In the mature niche, one likely source of SHH ligand is local neurons in neighboring areas, as indicated by blue cell placement. $\boldsymbol{B}$, During circuit assembly in the postnatal cortex, Shh is expressed by deep layer subcortical projection neurons and functions to guide synapse formation with Boc expressing intracortical projection neurons within layer V. As the cortex matures, a subset of differentiated astrocytes expresses $G$ lii. $C$, Axon guidance in the developing visual system, where Shh is expressed exclusively by contra-RGCs, whereas Boc and Ptch2 are expressed by ipsi-RGCs. Shh from contra-RGCs repels ipsi-RGCs, facilitating proper axon sorting and eye-specific segregation. $\boldsymbol{D}$, Maintenance of specialized astrocyte phenotypes in mature circuitry of the cerebellum. BG adopt specific molecular programs in response to SHH produced by neighboring PCS.

logically defined, Gli1 astrocytes in the forebrain are distributed both between and within distinct regions. Gli1 astrocytes are absent from all white matter tracts, but are found with varying ratios to Glil-negative astrocytes throughout the hypothalamus, thalamus, globus pallidus, septum, and cortex (Garcia et al., 2010). Whether Shh drives distinct molecular or functional properties of Glil astrocytes throughout these regions, as has been observed in the cerebellum, is an area of active research.

\section{Shh signaling during brain injury and repair}

Although the functional significance of Shh signaling to astrocytes remains largely unknown, current efforts aimed at understanding its role in astrocyte function have focused largely on its role in injury and neural repair. Astrocytes are central to the injury response in the pathological CNS, mitigating secondary damage through the production of the glial scar (Sofroniew, 2014). It has been widely reported that both SHH and GLI1 increase in response to various injury models, including stroke and stab wound and spinal cord injury (Bambakidis et al., 2003; Amankulor et al., 2009; Sims et al., 2009; Bambakidis et al., 2010; Pitter et al., 2014; Jin et al., 2015). Both pharmacological and genetic interruption of Shh signaling reduce proliferation of reactive astrocytes (Amankulor et al., 2009), which are required for the production of a glial scar (Wanner et al., 2013). This suggests that SHH may promote neural repair mechanisms through its actions as a mitogen. Indeed, Shh signaling may promote proliferation of local neural progenitors, as discussed above, and has even been suggested to promote the adoption of NSC properties by reactive astrocytes (Bambakidis et al., 2003; Bambakidis et al., 2010; Sirko et al., 2013).

Beyond their role in glial scar formation, astrocyte interactions with endothelial cells are critical for maintaining the BBB (Abbott et al., 2006). Shh signaling between astrocytes and endothelial cells restricts the permeability of the $\mathrm{BBB}$, limiting the extravasation of blood-derived inflammatory molecules into the CNS (Alvarez et al., 2011). In addition, promoting Shh activity dramatically reduces the infiltration of blood-borne macrophages into the CNS after a stab wound injury (R.V. Allahyari and A.D.R.G., unpublished observations). This effect is abolished in conditional mutants in which Smo is selectively deleted in astrocytes, suggesting a requirement for Shh signaling. Together, these observations suggest that Shh signaling in astrocytes mitigates inflammation and may provide neuroprotective benefit to reorganization and restoration of homeostasis to tissues following injury. 
In contrast to reports describing upregulation of Shh in reactive astrocytes, emerging studies have demonstrated a loss of Shh signaling after injury. Using genetic labeling strategies, Gli1 expression in astrocytes is downregulated after injury, suggesting that Shh signaling does not persist in reactive astrocytes (Mierzwa et al., 2014) (R.V. Allahyari and A.D.R.G., unpublished observations). A major distinction between these studies and those reporting an increase in SHH and GLI1 is the use of genetic tools to identify GLI1-expressing cells. Whereas earlier reports have relied primarily on antibody labeling to identify SHH and GLI1, studies reporting a reduction in Gli1 have relied on genetic mouse models in which a tamoxifen-inducible Cre is targeted to the Gli1 locus, enabling cell- and temporally specific expression of reporter proteins (Ahn and Joyner, 2004). Resolving these apparently conflicting observations will be an important step toward gaining a better understanding of Shh signaling in astrocyte function.

\section{Conclusion}

As discussed herein, a growing body of research has demonstrated diverse functional requirements for Shh signaling in the developing and mature nervous system. Although the core components of this pathway recur in many of these cases, the diversity of coreceptors and downstream pathway components that can modulate Ptc1, Smo, and Gli1 mean that this pathway can act in cell-type- and context-dependent patterns to execute a wide variety of cellular programs. Future research focused on the delivery and contextual interpretation of Shh signals by differing neural cell types will continue to enhance our understanding of this adaptable, multifunctional pathway.

\section{References}

Abbott NJ, Rönnbäck L, Hansson E (2006) Astrocyte-endothelial interactions at the blood-brain barrier. Nat Rev Neurosci 7:41-53. CrossRef Medline

Ahn S, Joyner AL (2004) Dynamic changes in the response of cells to positive hedgehog signaling during mouse limb patterning. Cell 118:505-516. CrossRef Medline

Ahn S, Joyner AL (2005) In vivo analysis of quiescent adult neural stem cells responding to sonic hedgehog. Nature 437:894-897. CrossRef Medline

Allen BL, Song JY, Izzi L, Althaus IW, Kang JS, Charron F, Krauss RS, McMahon AP (2011) Overlapping roles and collective requirement for the coreceptors GAS1, CDO, and BOC in SHH pathway function. Dev Cell 20:775-787. CrossRef Medline

Allen NJ, Eroglu C (2017) Cell biology of astrocyte-synapse interactions. Neuron 96:697-708. CrossRef Medline

Alvarez JI, Dodelet-Devillers A, Kebir H, Ifergan I, Fabre PJ, Terouz S, Sabbagh M, Wosik K, Bourbonnière L, Bernard M, van Horssen J, de Vries HE, Charron F, Prat A (2011) The hedgehog pathway promotes bloodbrain barrier integrity and CNS immune quiescence. Science 334:17271731. CrossRef Medline

Amankulor NM, Hambardzumyan D, Pyonteck SM, Becher OJ, Joyce JA, Holland EC (2009) Sonic hedgehog pathway activation is induced by acute brain injury and regulated by injury-related inflammation. J Neurosci 29:10299-10308. CrossRef Medline

Balordi F, Fishell G (2007a) Mosaic removal of hedgehog signaling in the adult SVZ reveals that the residual wild-type stem cells have a limited capacity for self-renewal. J Neurosci 27:14248-14259. CrossRef Medline

Balordi F, Fishell G (2007b) Hedgehog signaling in the subventricular zone is required for both the maintenance of stem cells and the migration of newborn neurons. J Neurosci 27:5936-5947. CrossRef Medline

Bambakidis NC, Wang RZ, Franic L, Miller RH (2003) Sonic hedgehoginduced neural precursor proliferation after adult rodent spinal cord injury. J Neurosurg 99:70-75. Medline

Bambakidis NC, Wang X, Lukas RJ, Spetzler RF, Sonntag VK, Preul MC (2010) Intravenous hedgehog agonist induces proliferation of neural and oligodendrocyte precursors in rodent spinal cord injury. Neurosurgery 67:1709-1715. CrossRef Medline
Belgacem YH, Hamilton AM, Shim S, Spencer KA, Borodinsky LN (2016) The many hats of sonic hedgehog signaling in nervous system development and disease. J Dev Biol 4:E35. CrossRef Medline

Bellamy TC (2007) Presynaptic modulation of parallel fibre signalling to bergmann glia. Neuropharmacology 52:368-375. CrossRef Medline

Bourikas D, Pekarik V, Baeriswyl T, Grunditz A, Sadhu R, Nardó M, Stoeckli ET (2005) Sonic hedgehog guides commissural axons along the longitudinal axis of the spinal cord. Nat Neurosci 8:297-304. CrossRef Medline

Buffo A, Rossi F (2013) Origin, lineage and function of cerebellar glia. Prog Neurobiol 109:42-63. CrossRef Medline

Burke R, Nellen D, Bellotto M, Hafen E, Senti KA, Dickson BJ, Basler K (1999) Dispatched, a novel sterol-sensing domain protein dedicated to the release of cholesterol-modified hedgehog from signaling cells. Cell 99:803-815. CrossRef Medline

Cahoy JD, Emery B, Kaushal A, Foo LC, Zamanian JL, Christopherson KS, Xing Y, Lubischer JL, Krieg PA, Krupenko SA, Thompson WJ, Barres BA (2008) A transcriptome database for astrocytes, neurons, and oligodendrocytes: a new resource for understanding brain development and function. J Neurosci 28:264-278. CrossRef Medline

Chan-Palay V, Palay SL (1972) The form of velate astrocytes in the cerebellar cortex of monkey and rat: high voltage electron microscopy of rapid golgi preparations. Z Anat Entwicklungsgesch 138:1-19. CrossRef Medline

Charron F, Stein E, Jeong J, McMahon AP, Tessier-Lavigne M (2003) The morphogen sonic hedgehog is an axonal chemoattractant that collaborates with netrin-1 in midline axon guidance. Cell 113:11-23. CrossRef Medline

Chuang PT, McMahon AP (1999) Vertebrate hedgehog signalling modulated by induction of a hedgehog-binding protein. Nature 397:617-621. CrossRef Medline

Chu T, Chiu M, Zhang E, Kunes S (2006) A C-terminal motif targets hedgehog to axons, coordinating assembly of the Drosophila eye and brain. Dev Cell 10:635-646. CrossRef Medline

Dave RK, Ellis T, Toumpas MC, Robson JP, Julian E, Adolphe C, Bartlett PF, Cooper HM, Reynolds BA, Wainwright BJ (2011) Sonic hedgehog and notch signaling can cooperate to regulate neurogenic divisions of neocortical progenitors. PLoS One 6:e14680. CrossRef Medline

Daynac M, Tirou L, Faure H, Mouthon MA, Gauthier LR, Hahn H, Boussin FD, Ruat M (2016) Hedgehog controls quiescence and activation of neural stem cells in the adult ventricular-subventricular zone. Stem Cell Reports 7:735-748. CrossRef Medline

de Juan Romero C, Bruder C, Tomasello U, Sanz-Anquela JM, Borrell V (2015) Discrete domains of gene expression in germinal layers distinguish the development of gyrencephaly. EMBO J 34:1859-1874. CrossRef Medline

Derwińska K, Smyk M, Cooper ML, Bader P, Cheung SW, Stankiewicz P (2009) PTCH1 duplication in a family with microcephaly and mild developmental delay. Eur J Hum Genet 17:267-271. CrossRef Medline

Echelard Y, Epstein DJ, St-Jacques B, Shen L, Mohler J, McMahon JA, McMahon AP (1993) Sonic hedgehog, a member of a family of putative signaling molecules, is implicated in the regulation of CNS polarity. Cell 75:1417-1430. CrossRef Medline

Ericson J, Muhr J, Placzek M, Lints T, Jessell TM, Edlund T (1995) Sonic hedgehog induces the differentiation of ventral forebrain neurons: a common signal for ventral patterning within the neural tube. Cell 81:747-756. CrossRef Medline

Evans TA, Bashaw GJ (2010) Axon guidance at the midline: of mice and flies. Curr Opin Neurobiol 20:79-85. CrossRef Medline

Fabre PJ, Shimogori T, Charron F (2010) Segregation of ipsilateral retinal ganglion cell axons at the optic chiasm requires the shh receptor boc. J Neurosci 30:266-275. CrossRef Medline

Farmer WT, Murai K (2017) Resolving astrocyte heterogeneity in the CNS. Front Cell Neurosci 11:300. CrossRef Medline

Farmer WT, Abrahamsson T, Chierzi S, Lui C, Zaelzer C, Jones EV, Bally BP, Chen GG, Théroux JF, Peng J, Bourque CW, Charron F, Ernst C, Sjöström PJ, Murai KK (2016) Neurons diversify astrocytes in the adult brain through sonic hedgehog signaling. Science 351:849-854. CrossRef Medline

Fuccillo M, Joyner AL, Fishell G (2006) Morphogen to mitogen: the multiple roles of hedgehog signalling in vertebrate neural development. Nat Rev Neurosci 7:772-783. CrossRef Medline

Garcia AD, Petrova R, Eng L, Joyner AL (2010) Sonic hedgehog regulates 
discrete populations of astrocytes in the adult mouse forebrain. J Neurosci 30:13597-13608. CrossRef Medline

Han YG, Spassky N, Romaguera-Ros M, Garcia-Verdugo JM, Aguilar A, Schneider-Maunoury S, Alvarez-Buylla A (2008) Hedgehog signaling and primary cilia are required for the formation of adult neural stem cells. Nat Neurosci 11:277-284. CrossRef Medline

Harwell CC, Parker PR, Gee SM, Okada A, McConnell SK, Kreitzer AC, Kriegstein AR (2012) Sonic hedgehog expression in corticofugal projection neurons directs cortical microcircuit formation. Neuron 73:11161126. CrossRef Medline

Heussler HS, Suri M, Young ID, Muenke M (2002) Extreme variability of expression of a sonic hedgehog mutation: attention difficulties and holoprosencephaly. Arch Dis Child 86:293-296. CrossRef Medline

Hoogland TM, Kuhn B (2010) Recent developments in the understanding of astrocyte function in the cerebellum in vivo. Cerebellum 9:264-271. CrossRef Medline

Ihrie RA, Shah JK, Harwell CC, Levine JH, Guinto CD, Lezameta M, Kriegstein AR, Alvarez-Buylla A (2011) Persistent sonic hedgehog signaling in adult brain determines neural stem cell positional identity. Neuron 71:250-262. CrossRef Medline

Iino M, Goto K, Kakegawa W, Okado H, Sudo M, Ishiuchi S, Miwa A, Takayasu Y, Saito I, Tsuzuki K, Ozawa S (2001) Glia-synapse interaction through Ca2+-permeable AMPA receptors in Bergmann glia. Science 292:926-929. CrossRef Medline

Izumi K, Hahn A, Christ L, Curtis C, Neilson DE (2011) Familial 9q22.3 microduplication spanning PTCH1 causes short stature syndrome with mild intellectual disability and dysmorphic features. Am J Med Genet A 155A:1384-1389. CrossRef Medline

Jin Y, Raviv N, Barnett A, Bambakidis NC, Filichia E, Luo Y (2015) The Shh signaling pathway is upregulated in multiple cell types in cortical ischemia and influences the outcome of stroke in an animal model. PLoS One 10:e0124657. CrossRef Medline

Kennedy TE, Wang H, Marshall W, Tessier-Lavigne M (2006) Axon guidance by diffusible chemoattractants: a gradient of netrin protein in the developing spinal cord. J Neurosci 26:8866-8874. CrossRef Medline

Kohtz JD, Baker DP, Corte G, Fishell G (1998) Regionalization within the mammalian telencephalon is mediated by changes in responsiveness to sonic hedgehog. Development 125:5079-5089. Medline

Komada M, Saitsu H, Kinboshi M, Miura T, Shiota K, Ishibashi M (2008) Hedgehog signaling is involved in development of the neocortex. Development (Cambridge, England) 135:2717-2727. CrossRef Medline

Lai K, Kaspar BK, Gage FH, Schaffer DV (2003) Sonic hedgehog regulates adult neural progenitor proliferation in vitro and in vivo. Nat Neurosci 6:21-27. CrossRef Medline

Lancaster MA, Renner M, Martin CA, Wenzel D, Bicknell LS, Hurles ME, Homfray T, Penninger JM, Jackson AP, Knoblich JA (2013) Cerebral organoids model human brain development and microcephaly. Nature 501:373-379. CrossRef Medline

Lepelletier L, Langlois SD, Kent CB, Welshhans K, Morin S, Bassell GJ, Yam PT, Charron F (2017) Sonic hedgehog guides axons via zipcode binding protein 1-mediated local translation. J Neurosci 37:1685-1695. CrossRef Medline

Lewitus E, Kelava I, Kalinka AT, Tomancak P, Huttner WB (2014) An adaptive threshold in mammalian neocortical evolution. PLoS Biol 12: e1002000. CrossRef Medline

Machold R, Hayashi S, Rutlin M, Muzumdar MD, Nery S, Corbin JG, GritliLinde A, Dellovade T, Porter JA, Rubin LL, Dudek H, McMahon AP, Fishell G (2003) Sonic hedgehog is required for progenitor cell maintenance in telencephalic stem cell niches. Neuron 39:937-950. CrossRef Medline

Masdeu C, Bernard V, Faure H, Traiffort E, Ruat M (2007) Distribution of smoothened at hippocampal mossy fiber synapses. Neuroreport 18:395399. CrossRef Medline

Mierzwa AJ, Sullivan GM, Beer LA, Ahn S, Armstrong RC (2014) Comparison of cortical and white matter traumatic brain injury models reveals differential effects in the subventricular zone and divergent sonic hedgehog signaling pathways in neuroblasts and oligodendrocyte progenitors. ASN Neuro 6:1759091414551782. CrossRef Medline

Mitchell N, Petralia RS, Currier DG, Wang YX, Kim A, Mattson MP, Yao PJ (2012) Sonic hedgehog regulates presynaptic terminal size, ultrastructure and function in hippocampal neurons. J Cell Sci 125:4207-4213. CrossRef Medline
Okada A, Charron F, Morin S, Shin DS, Wong K, Fabre PJ, Tessier-Lavigne M, McConnell SK (2006) Boc is a receptor for sonic hedgehog in the guidance of commissural axons. Nature 444:369-373. CrossRef Medline

Peng J, Fabre PJ, Dolique T, Swikert SM, Kermasson L, Shimogori T, Charron F (2018) Sonic hedgehog is a remotely produced cue that controls axon guidance trans-axonally at a midline choice point. Neuron 97:326340.e4. CrossRef Medline

Petralia RS, Schwartz CM, Wang YX, Mattson MP, Yao PJ (2011) Subcellular localization of patched and smoothened, the receptors for sonic hedgehog signaling, in the hippocampal neuron. J Comp Neurol 519:3684-3699. CrossRef Medline

Petrova R, Garcia AD, Joyner AL (2013) Titration of GLI3 repressor activity by sonic hedgehog signaling is critical for maintaining multiple adult neural stem cell and astrocyte functions. J Neurosci 33:17490-17505. CrossRef Medline

Pitter KL, Tamagno I, Feng X, Ghosal K, Amankulor N, Holland EC, Hambardzumyan D (2014) The SHH/Gli pathway is reactivated in reactive glia and drives proliferation in response to neurodegeneration-induced lesions. Glia 62:1595-1607. CrossRef Medline

Ramón y Cajal S (1911) Histologie du système nerveux de l'homme \& des vertébrés. Paris, Maloine, 1909-1911.

Riddle RD, Johnson RL, Laufer E, Tabin C (1993) Sonic hedgehog mediates the polarizing activity of the ZPA. Cell 75:1401-1416. CrossRef Medline

Robles E, Woo S, Gomez TM (2005) Src-dependent tyrosine phosphorylation at the tips of growth cone filopodia promotes extension. J Neurosci 25:7669-7681. CrossRef Medline

Rothstein JD, Martin L, Levey AI, Dykes-Hoberg M, Jin L, Wu D, Nash N, Kuncl RW (1994) Localization of neuronal and glial glutamate transporters. Neuron 13:713-725. CrossRef Medline

Rubin JB, Choi Y, Segal RA (2002) Cerebellar proteoglycans regulate sonic hedgehog responses during development. Development 129:2223-2232. Medline

Saab AS, Neumeyer A, Jahn HM, Cupido A, Simek AA, Boele HJ, Scheller A, Le Meur K, Götz M, Monyer H, Sprengel R, Rubio ME, Deitmer JW, De Zeeuw CI, Kirchhoff F (2012) Bergmann glial AMPA receptors are required for fine motor coordination. Science 337:749-753. CrossRef Medline

Samanta J, Grund EM, Silva HM, Lafaille JJ, Fishell G, Salzer JL (2015) Inhibition of Gli1 mobilizes endogenous neural stem cells for remyelination. Nature 526:448-452. CrossRef Medline

Sánchez-Arrones L, Nieto-Lopez F, Sánchez-Camacho C, Carreres MI, Herrera E, Okada A, Bovolenta $\mathrm{P}$ (2013) Shh/Boc signaling is required for sustained generation of ipsilateral projecting ganglion cells in the mouse retina. J Neurosci 33:8596-8607. CrossRef Medline

Sánchez-Camacho C, Bovolenta P (2008) Autonomous and non-autonomous shh signalling mediate the in vivo growth and guidance of mouse retinal ganglion cell axons. Development 135:3531-3541. CrossRef Medline

Sanders TA, Llagostera E, Barna M (2013) Specialized filopodia direct longrange transport of SHH during vertebrate tissue patterning. Nature 497: 628-632. CrossRef Medline

Shikata Y, Okada T, Hashimoto M, Ellis T, Matsumaru D, Shiroishi T, Ogawa M, Wainwright B, Motoyama J (2011) Ptch1-mediated dosage-dependent action of shh signaling regulates neural progenitor development at late gestational stages. Dev Biol 349:147-159. CrossRef Medline

Shin J, Berg DA, Zhu Y, Shin JY, Song J, Bonaguidi MA, Enikolopov G, Nauen DW, Christian KM, Ming GL, Song H (2015) Single-cell RNA-seq with waterfall reveals molecular cascades underlying adult neurogenesis. Cell Stem Cell 17:360-372. CrossRef Medline

Sims JR, Lee SW, Topalkara K, Qiu J, Xu J, Zhou Z, Moskowitz MA (2009) Sonic hedgehog regulates ischemia/hypoxia-induced neural progenitor proliferation. Stroke 40:3618-3626. CrossRef Medline

Sirko S, et al. (2013) Reactive glia in the injured brain acquire stem cell properties in response to sonic hedgehog glia. Cell Stem Cell 12:426-439. CrossRef Medline

Sofroniew MV (2014) Astrogliosis. Cold Spring Harb Perspect Biol 7:a020420. CrossRef Medline

Sofroniew MV, Vinters HV (2010) Astrocytes: biology and pathology. Acta Neuropathologica 119:7-35. Medline

Takayasu Y, Iino M, Shimamoto K, Tanaka K, Ozawa S (2006) Glial glutamate transporters maintain one-to-one relationship at the climbing fiberPurkinje cell synapse by preventing glutamate spillover. J Neurosci 26: 6563-6572. CrossRef Medline 
Tong CK, Fuentealba LC, Shah JK, Lindquist RA, Ihrie RA, Guinto CD, Rodas-Rodriguez JL, Alvarez-Buylla A (2015) A dorsal SHH-dependent domain in the V-SVZ produces large numbers of oligodendroglial lineage cells in the postnatal brain. Stem Cell Reports 5:461-470. CrossRef Medline

Traiffort E, Charytoniuk D, Watroba L, Faure H, Sales N, Ruat M (1999) Discrete localizations of hedgehog signalling components in the developing and adult rat nervous system. Eur J Neurosci 11:3199-3214. CrossRef Medline

Trousse F, Martí E, Gruss P, Torres M, Bovolenta P (2001) Control of retinal ganglion cell axon growth: a new role for sonic hedgehog. Development 128:3927-3936. Medline

Tukachinsky H, Petrov K, Watanabe M, Salic A (2016) Mechanism of inhibition of the tumor suppressor patched by sonic hedgehog. Proc Natl Acad Sci U S A 113:E5866-E5875. CrossRef Medline

Wang F, Smith NA, Xu Q, Fujita T, Baba A, Matsuda T, Takano T, Bekar L, Nedergaard M (2012) Astrocytes modulate neural network activity by $\mathrm{Ca}(2)+$-dependent uptake of extracellular $\mathrm{K}+$. Sci Signal 5:ra26. CrossRef Medline

Wang H, Ge G, Uchida Y, Luu B, Ahn S (2011) Gli3 is required for maintenance and fate specification of cortical progenitors. J Neurosci 31:64406448. CrossRef Medline

Wang L, Hou S, Han YG (2016) Hedgehog signaling promotes basal progenitor expansion and the growth and folding of the neocortex. Nat Neurosci 19:888-896. CrossRef Medline

Wanner IB, Anderson MA, Song B, Levine J, Fernandez A, Gray-Thompson Z, Ao Y, Sofroniew MV (2013) Glial scar borders are formed by newly proliferated, elongated astrocytes that interact to corral inflammatory and fibrotic cells via STAT3-dependent mechanisms after spinal cord injury. J Neurosci 33:12870-12886. CrossRef Medline

Wechsler-Reya RJ, Scott MP (1999) Control of neuronal precursor proliferation in the cerebellum by sonic hedgehog. Neuron 22:103-114. CrossRef Medline

Wilson NH, Stoeckli ET (2013) Sonic hedgehog regulates its own receptor on postcrossing commissural axons in a glypican1-dependent manner. Neuron 79:478-491. CrossRef Medline

Winkler CC, Yabut OR, Fregoso SP, Gomez HG, Dwyer BE, Pleasure SJ, Franco SJ (2018) The dorsal wave of neocortical oligodendrogenesis begins embryonically and requires multiple sources of sonic hedgehog. J Neurosci 38:5237-5250. CrossRef Medline

Yabut OR, Fernandez G, Huynh T, Yoon K, Pleasure SJ (2015) Suppressor of fused is critical for maintenance of neuronal progenitor identity during corticogenesis. Cell Reports 12:2021-2034. CrossRef Medline

Yam PT, Charron F (2013) Signaling mechanisms of non-conventional axon guidance cues: the shh, BMP and Wnt morphogens. Curr Opin Neurobiol 23:965-973. CrossRef Medline

Yam PT, Langlois SD, Morin S, Charron F (2009) Sonic hedgehog guides axons through a noncanonical, Src-family-kinase-dependent signaling pathway. Neuron 62:349-362. CrossRef Medline

Yam PT, Kent CB, Morin S, Farmer WT, Alchini R, Lepelletier L, Colman DR, Tessier-Lavigne M, Fournier AE, Charron F (2012) 14-3-3 proteins regulate a cell-intrinsic switch from sonic hedgehog-mediated commissural axon attraction to repulsion after midline crossing. Neuron 76:735-749. CrossRef Medline

Zuñiga NR, Stoeckli ET (2017) Sonic: 'jack-of-all-trades' in neural circuit formation. J Dev Biol 5:E2. CrossRef Medline 